\title{
Dichloro and dimethyl dioxomolybdenum(vI)-diazabutadiene complexes as catalysts for the epoxidation of olefins
}

\author{
Anabela A. Valente, ${ }^{a}$ José Moreira, ${ }^{b}$ André D. Lopes, ${ }^{* b}$ Martyn Pillinger, ${ }^{a}$ Carla D. Nunes, ${ }^{a}$ \\ Carlos C. Romão, ${ }^{c}$ Fritz E. Kühn ${ }^{d}$ and Isabel S. Gonçalves ${ }^{* a}$ \\ ${ }^{a}$ Department of Chemistry, CICECO, University of Aveiro, 3810-193, Aveiro, Portugal \\ E-mail: igoncalves@dq.ua.pt \\ ${ }^{b}$ Department of Chemistry and Biochemistry, Faculty of Science and Technology, University of \\ the Algarve, Campus de Gambelas, 8000-062, Faro, Portugal \\ c Instituto de Tecnologia Química e Biológica, Universidade Nova de Lisboa, Quinta do \\ Marquês, EAN, Apt 127, 2780-901, Oeiras, Portugal \\ d Anorganisch-chemisches Institut, Technische Universität München, Lichtenbergstrasse 4 \\ D-85747, Garching bei München, Germany
}

Received (in Montpellier, France) 11th September 2003, Accepted 30th October 2003

First published as an Advance Article on the web 16th January 2004

The dioxomolybdenum(vI) complex $\left[\mathrm{MoO}_{2} \mathrm{Cl}_{2}\left\{p\right.\right.$-tolyl $\left.\left.\left(\mathrm{CH}_{3} \mathrm{DAB}\right)\right\}\right]$ has been prepared in good yield by reaction of the solvent adduct $\mathrm{MoO}_{2} \mathrm{Cl}_{2}(\mathrm{THF})_{2}$ with one equivalent of the bidentate ligand $N, N$ - $p$-tolyl-2,3-dimethyl1,4-diazabutadiene. Treatment of the dichloro complex with the Grignard reagent $\mathrm{CH}_{3} \mathrm{MgCl}$ gives the dimethyl derivative $\left[\mathrm{MoO}_{2}\left(\mathrm{CH}_{3}\right)_{2}\left\{p\right.\right.$-tolyl $\left.\left.\left(\mathrm{CH}_{3} \mathrm{DAB}\right)\right\}\right]$. The complexes are highly active and selective catalysts for the homogeneous epoxidation of cyclooctene using tert-butyl hydroperoxide (TBHP) as the oxidant. In both cases, the initial activity is $c a .175 \mathrm{~mol} \mathrm{~mol}^{-1} \mathrm{Mo} \mathrm{h}^{-1}$ and cyclooctene oxide is obtained quantitatively within $4 \mathrm{~h}$. It was possible to recover the dimethyl complex at the end of the reaction and reuse it in a second run with only a small decrease in activity. The complexes are also active and selective for the epoxidation of other olefins, such as 1-octene, 2-octene, cyclododecene and $(R)-(+)$-limonene, with TBHP. The catalytic production of cyclooctene oxide was investigated in detail, varying either the reaction temperature or the initial concentrations of substrate, oxidant and catalyst precursor. Kinetic studies show that the catalyst precursor-oxygen donor complex formation is first-order in TBHP and in the metal complex $\left[\mathrm{MoO}_{2} \mathrm{Cl}_{2}\left\{p\right.\right.$-tolyl $\left.\left.\left(\mathrm{CH}_{3} \mathrm{DAB}\right)\right\}\right]$. A specific rate of $3.2 \mathrm{~mol}^{-1} \mathrm{dm}^{3} \mathrm{~s}^{-1}$ was found for catalyst formation at $25^{\circ} \mathrm{C}$. Activation parameters for this reaction have also been measured $\left(\Delta H^{\neq}=48 \pm 3 \mathrm{~kJ} \mathrm{~mol}^{-1}, \Delta S^{\neq}=-112 \pm 10 \mathrm{~J} \mathrm{~mol}^{-1} \mathrm{~K}^{-1}\right)$.

\section{Introduction}

Homogeneous molybdenum(vi) catalysts are the basis of important industrial processes for the epoxidation of propylene with alkyl hydroperoxides as the oxygen source. ${ }^{1}$ As a result, there is considerable interest in the synthesis of new Mo (and W) complexes for the epoxidation of olefins..$^{2-6}$ Recently, it has been shown that complexes of the type $\left[\mathrm{MoO}_{2} \mathrm{X}_{2}(\mathrm{~L})_{n}\right]\left(\mathrm{X}=\mathrm{Cl}, \mathrm{Br}, \mathrm{CH}_{3} ; \mathrm{L}=\right.$ mono or bidentate neutral N-ligand) are flexible catalyst precursors for the epoxidation of olefins in the presence of tert-butyl hydroperoxide (TBHP). ${ }^{7-9}$ The complexes usually exhibit a distorted octahedral geometry with a cis,trans, cis configuration. Variation of $\mathrm{X}$ or L allows a fine-tuning of the ligand surroundings of the molybdenum(vi) centre. It was reported that, at least with $\mathrm{L}=$ bipyridine (bipy) and bipyrimidine (bpym), the chlorine derivatives are more active as epoxidation catalysts than the bromine complexes, which are only slightly more active than the methyl complexes. ${ }^{10}$ A mechanism has been proposed in which the HOO proton is transferred to one of the terminal oxygen atoms and the ${ }^{-}$OOR group coordinates as a seventh ligand in a $\eta^{1}$ manner to the Mo centre. ${ }^{10,11}$ The reaction continues by approach of the olefin to the coordinated $\alpha$ oxygen.

Unfortunately, dioxomolybdenum(vi) complexes with polypyridyl ligands (bipy and bpym) are rather slow catalysts of low general activity. Substituted 1,4-diazabutadienes seem to be more promising as supporting ligands. ${ }^{7 b}$ In the present work, we describe the preparation of $\left[\mathrm{MoO}_{2} \mathrm{X}_{2} \mathrm{~L}\right]$-type
$\left(\mathrm{X}=\mathrm{Cl}, \mathrm{CH}_{3}\right) \quad$ complexes $(\mathrm{Chart} 1)$ with $\mathrm{L}=N, N-p$ tolyl-2,3-dimethyl-1,4-diazabutadiene $\left[p\right.$-tolyl $\left.\left(\mathrm{CH}_{3} \mathrm{DAB}\right)\right]$ and characterise their catalytic activity and kinetics in cyclooctene epoxidation using TBHP as the oxidant. Up until fairly recently, most of the known organometallic dioxomolybdenum complexes were restricted to complexes of formula $\left[\mathrm{MoO}_{2} \mathrm{R}_{2}\right.$ (bipy) $\left(\mathrm{R}=\right.$ methyl, ethyl, neopentyl, $\mathrm{C}_{6} \mathrm{H}_{5}, \mathrm{CH}_{2} \mathrm{Ph}$, $\mathrm{CH}_{2} \mathrm{CH}_{2} \mathrm{Ph}$, p- $\mathrm{CH}_{3} \mathrm{C}_{6} \mathrm{H}_{4} \mathrm{CH}_{2}$, etc. $){ }^{12}$ The poor solubility imparted by bipy to these complexes has limited the number and scope of spectroscopic investigations. In 2002, Wong et al. reported new alkyl derivatives chelated with $\mathrm{N}_{2} \mathrm{O}$ tridentate ligands. ${ }^{6 d}$ We have developed reproducible syntheses for Mo-oxo-alkyl complexes with various bidentate N-ligands,

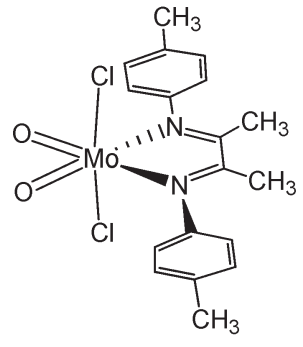

1

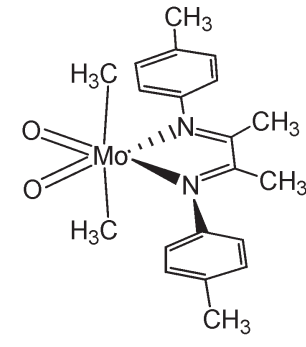

2
Chart 1 
including bpym, and the X-ray structure of $\left[\mathrm{MoO}_{2}\left(\mathrm{CH}_{3}\right)_{2}\right.$ (bpym)] was reported. ${ }^{7 c}$ One aim of the present work is to examine how catalytic behaviour is influenced by changing the nature of $\mathrm{X}$ from $\mathrm{Cl}$ to $\mathrm{CH}_{3}$, in an otherwise identical molecule.

\section{Experimental}

\section{General methods}

All preparations and manipulations were carried out using standard Schlenk techniques under nitrogen. Solvents were dried by standard procedures (hexane, diethyl ether and THF over Na/benzophenone ketyl, $\mathrm{CH}_{2} \mathrm{Cl}_{2}$ and $\mathrm{CH}_{3} \mathrm{CN}$ over $\mathrm{CaH}_{2}$ ), distilled under nitrogen and stored over $4 \AA$ molecular sieves ( $3 \AA$ for $\mathrm{CH}_{3} \mathrm{CN}$ ). TBHP (5.5 M solution in decane) was purchased from Aldrich and used as received.

Microanalyses were performed at the University of Aveiro. ${ }^{1} \mathrm{H}-\mathrm{NMR}$ spectra were recorded at $300 \mathrm{MHz}$ using a Bruker CXP 300 spectrometer. ${ }^{13} \mathrm{C}$-NMR spectra were recorded at 100.28 MHz using a Bruker Avance DPX-400 spectrometer. IR spectra were obtained as $\mathrm{KBr}$ pellets using a FTIR Mattson-7000 infrared spectrophotometer. Raman spectra were recorded on a Bruker RFS 100/S FT Raman spectrometer using $1064 \mathrm{~nm}$ excitation from a Nd/YAG laser.

Literature methods were used to prepare the compounds $\left[\mathrm{MoO}_{2} \mathrm{Cl}_{2}\right],{ }^{13}\left[\mathrm{MoO}_{2} \mathrm{Cl}_{2}(\mathrm{THF})_{2}\right],{ }^{14}$ and $p$-tolyl $\left(\mathrm{CH}_{3} \mathrm{DAB}\right) .{ }^{15}$

\section{Syntheses}

[ $\mathrm{MoO}_{2} \mathrm{Cl}_{2}(\mathrm{~N}, \mathrm{~N}$-p-tolyl-2,3-dimethyl-1,4-diazabutadiene)], 1 . A solution of $\left[\mathrm{MoO}_{2} \mathrm{Cl}_{2}(\mathrm{THF})_{2}\right](1.03 \mathrm{~g}, 3.0 \mathrm{mmol})$ in THF $(20 \mathrm{~mL})$ was treated with $N, N$-p-tolyl-2,3-dimethyl-1,4diazabutadiene $(0.79 \mathrm{~g}, 3.0 \mathrm{mmol})$ and the mixture stirred vigorously for $30 \mathrm{~min}$. The resulting yellow solution was evaporated to dryness to yield the adduct $\mathbf{1}$ as a pale yellow microcrystalline powder $(1.31 \mathrm{~g}, 94 \%)$. Anal. found: C, 46.50; $\mathrm{H}, 4.38 ; \mathrm{N}, 6.08 ; \mathrm{C}_{18} \mathrm{H}_{20} \mathrm{Cl}_{2} \mathrm{MoN}_{2} \mathrm{O}_{2}$ requires $\mathrm{C}$, 46.67; H, 4.35; N, 6.05. FTIR: $\nu_{\max } / \mathrm{cm}^{-1} 3021 \mathrm{~m}, 2919 \mathrm{~m}$, 1628 s, 1599 s, 1504 vs, $1436 \mathrm{~m}, 1374 \mathrm{~m}, 1238 \mathrm{~s}, 1204 \mathrm{~m}$, $1139 \mathrm{~m}, 942$ vs $\left(\nu_{\text {sym }} \mathrm{Mo}=\mathrm{O}\right), 910$ vs $\left(\nu_{\text {asym }} \mathrm{Mo}=\mathrm{O}\right), 863 \mathrm{~s}$, 837 s, 809 s, 792 s, 772 s, 643 m, 504 s, 490 s, 384 m, 345 s $(\mathrm{KBr})$; FT Raman: $\nu_{\max } / \mathrm{cm}^{-1} 3064 \mathrm{~m}, 2918 \mathrm{~m}, 1603 \mathrm{~m}$, $1206 \mathrm{~m}, 1178 \mathrm{~m}, 943 \mathrm{~m}, 933 \mathrm{~m}, 817 \mathrm{w}, 642 \mathrm{w}, 219 \mathrm{~m} ; \delta_{\mathrm{H}}$ [300 MHz, $\left.\mathrm{CD}_{2} \mathrm{Cl}_{2}, \mathrm{Si}\left(\mathrm{CH}_{3}\right)_{4}, 20^{\circ} \mathrm{C}\right]:$ 7.29-7.26 (m, 4H), 7.15-7.11 (m, 4H), $2.34(\mathrm{~s}, 6 \mathrm{H}), 2.26(\mathrm{~s}, 6 \mathrm{H})$.

[ $\mathrm{MoO}_{2}\left(\mathrm{CH}_{3}\right)_{2}(\mathrm{~N}, \mathrm{~N}$-p-tolyl-2,3-dimethyl-1,4-diazabutadiene)], 2. A solution of $\mathrm{CH}_{3} \mathrm{MgCl}$ in THF $(3 \mathrm{M}, 2.0 \mathrm{~mL}, 6.0 \mathrm{mmol})$ was added slowly to a suspension of $1(1.30 \mathrm{~g}, 2.8 \mathrm{mmol})$ in THF $(20 \mathrm{~mL})$ at $-20^{\circ} \mathrm{C}$ (isopropanol bath). The reaction mixture was allowed to warm up to room temperature and stirred for $1 \mathrm{~h}$. The dark red suspension was taken to dryness and ice-cold distilled water added. The product was extracted with dichloromethane and the organic phase dried over anhydrous $\mathrm{Na}_{2} \mathrm{SO}_{4}$. Finally, the solvent was removed under reduced pressure and the red residue recrystallised from $\mathrm{CH}_{2} \mathrm{Cl}_{2}$-diethyl ether (1.06 g, 90\%). Anal. found: C, 56.72; $\mathrm{H}, 6.16 ; \mathrm{N}, 6.58 ; \mathrm{C}_{20} \mathrm{H}_{26} \mathrm{MoN}_{2} \mathrm{O}_{2}$ requires $\mathrm{C}, 56.87 ; \mathrm{H}, 6.20$; $\mathrm{N}, 6.63 \%$. FTIR: $\nu_{\max } / \mathrm{cm}^{-1} 3025 \mathrm{~m}, 2956 \mathrm{~m}, 2915 \mathrm{~m}, 1505$ vs, $1445 \mathrm{~m}, 1420 \mathrm{~m}, 1379 \mathrm{~s}, 1232 \mathrm{~s}, 1136 \mathrm{~m}, 1111 \mathrm{~m}, 987 \mathrm{~m}$, 934 vs $\left(\nu_{\text {sym }} \mathrm{Mo}=\mathrm{O}\right), 907$ vs $\left(\nu_{\text {asym }} \mathrm{Mo}=\mathrm{O}\right), 859 \mathrm{~m}, 841 \mathrm{~m}$, $812 \mathrm{~m}, 781 \mathrm{~m}, 712 \mathrm{~m}, 550 \mathrm{~m}, 526 \mathrm{~m}, 506 \mathrm{~m}, 486 \mathrm{~m}(\mathrm{KBr})$; FT Raman: $\nu_{\max } / \mathrm{cm}^{-1} 3064,2920,1606,1553,1315,1204$, $1176,1140,987,935,904,858,621,468,413,228,134 ; \delta_{\mathrm{H}}$ [300 $\left.\mathrm{MHz}, \mathrm{CDCl}_{3}, \mathrm{Si}\left(\mathrm{CH}_{3}\right)_{4}, 20^{\circ} \mathrm{C}\right]: 7.21(\mathrm{~d}, 4 \mathrm{H}), 6.90(\mathrm{~d}$, $4 \mathrm{H}), 2.31(\mathrm{~s}, 6 \mathrm{H}), 2.25(\mathrm{~s}, 6 \mathrm{H}), 0.82(\mathrm{~s}, 6 \mathrm{H}) ; \delta_{\mathrm{C}}[100.28 \mathrm{MHz}$, $\left.\mathrm{CDCl}_{3}, \mathrm{Si}\left(\mathrm{CH}_{3}\right)_{4}, 20^{\circ} \mathrm{C}\right]: 165.1,146.8,137.0,129.8,120.4$, 21.1, 20.0.
Catalytic epoxidation of cyclooctene in the presence of 1 and 2

Cyclooctene $(3.6 \mathrm{mmol})$ and tert-butyl hydroperoxide (5.5 mmol, $5.5 \mathrm{M}$ solution in decane) were mixed in the presence of complex 1 or $2(36 \mu \mathrm{mol})$ in a glass microreactor, which was immersed in a thermostatted oil bath heated at $55^{\circ} \mathrm{C}$ and vigorously stirred (700-800 rpm). The epoxidation of other olefins was performed under identical reaction conditions. Conversion was monitored by taking samples and analysing them by gas chromatography using a capillary column (SPB-5, $20 \mathrm{~m} \times 0.25 \mathrm{~mm} \times 0.25 \mu \mathrm{m}$ ) and a flame ionisation detector. Cyclooctene epoxide was quantified using a calibration curve and undecane as internal standard (added after the reaction). Further experiments were carried out in the presence of complex $\mathbf{2}$, varying either the reaction temperature, initial concentration of cyclooctene, catalyst or oxidant. The reactions were carried out at constant total volume using decane as solvent.

\section{Kinetic studies of catalyst formation}

All kinetic measurements were carried out using a large excess of TBHP (pseudo-first-order conditions). Typically, an appropriate small quantity of concentrated TBHP in decane $(5.5 \mathrm{M})$ was added to a thermostatted UV quartz cell containing an appropriate amount of a solution of the metal complex in $\mathrm{CH}_{3} \mathrm{CN}$ in order to obtain a total volume of $3 \mathrm{~mL}$ with a final concentration of $\left[\mathrm{MoO}_{2} \mathrm{Cl}_{2}\left\{p\right.\right.$-tolyl $\left.\left.\left(\mathrm{CH}_{3} \mathrm{DAB}\right)\right\}\right]$ equal to $5 \times 10^{-4} \mathrm{M}$. The product formation was monitored against time by following absorbance changes at a specific wavelength in the range $300-500 \mathrm{~nm}$, using a Jasco V-560 spectrophotometer equipped with a Jasco EHC-477S Peltier thermostatted single cell holder.

\section{Results and discussion}

\section{Synthesis of dioxomolybdenum(vI) complexes}

The dioxomolybdenum(vI) complex $\left[\mathrm{MoO}_{2} \mathrm{Cl}_{2}\left\{p\right.\right.$-tolyl $\left(\mathrm{CH}_{3}\right.$ DAB) $\}$ ] (1) was obtained as a pale yellow microcrystalline powder in good yield by addition of 1 equiv. of the bidentate diimine ligand $p$-tolyl $\left(\mathrm{CH}_{3} \mathrm{DAB}\right)$ to a solution of the adduct $\left[\mathrm{MoO}_{2} \mathrm{Cl}_{2}(\mathrm{THF})_{2}\right]$ in THF at room temperature. The characterisation of compound $\mathbf{1}$ is straightforward and presents no surprises compared with other Lewis base adducts of bis(halogeno)dioxomolybdenum(vi) prepared using the same method. ${ }^{7 b}$ Treatment of $\mathbf{1}$ (ideally prepared in situ) with a slight excess of $\mathrm{CH}_{3} \mathrm{MgCl}$ at low temperature leads to the isolation of the dimethyl derivative $\left[\mathrm{MoO}_{2}\left(\mathrm{CH}_{3}\right)_{2}\left\{p\right.\right.$-tolyl $\left.\left.\left(\mathrm{CH}_{3} \mathrm{DAB}\right)\right\}\right]$ (2) in good yield. In the IR spectrum of $\mathbf{2}$, the symmetric and asymmetric $\mathrm{Mo}=\mathrm{O}$ stretching modes are observed at 934 and $907 \mathrm{~cm}^{-1}$, respectively. These are shifted to lower frequency compared with the dichloro precursor 1, suggesting a slight weakening of the $\mathrm{Mo}-\mathrm{O}$ bond. Similar trends are exhibited by 2,2'-bipyridine and 2,2'-bipyrimidine adducts of $\mathrm{MoO}_{2} \mathrm{X}_{2} \cdot{ }^{10}$ In the ${ }^{1} \mathrm{H}$ NMR spectrum of 2 , the set of signals due to the diimine ligand are only weakly shifted (to higher field) compared with those of compound $\mathbf{1}$. The chemical shift of the Mo-bonded $\mathrm{CH}_{3}$ substituent appears at $0.82 \mathrm{ppm}$ in agreement with the values reported in the literature for similar complexes. ${ }^{7 c}$ Both $\mathbf{1}$ and $\mathbf{2}$ are quite stable and can be handled under air for short periods of time. The organometallic derivative $\mathbf{2}$ is significantly more soluble in organic solvents than $\mathbf{1}$.

\section{Catalytic epoxidation of cis-cyclooctene}

The epoxidation of cyclooctene at $55^{\circ} \mathrm{C}$ using TBHP as oxidant and decane as solvent in the presence of complexes $\mathbf{1}$ or 2 (molar ratio of substrate:oxidant:catalyst $=100: 153: 1$ ) yields cyclooctene oxide as the only product. Control experiments confirmed that no reaction takes place in the absence 
of catalyst. The time-dependent curves obtained for compounds 1 and 2 are typical of $\left[\mathrm{MoO}_{2} \mathrm{X}_{2} \mathrm{~L}_{2}\right]$-type complexes used as epoxidation catalysts with TBHP. ${ }^{7}$ Initially the reaction is fast, indicating that the active oxidizing species are formed rapidly upon addition of the peroxide to the reaction medium. Progressively, the reaction rate decreases, which may result from the formation of tert-butyl alcohol (a by-product of the epoxidation), which competes with TBHP for coordination to the $\mathrm{Mo}^{\mathrm{vI}}$ centre (Scheme 1). ${ }^{10,11}$ Interestingly, the reaction rate of cyclooctene epoxidation is roughly the same for both catalysts. The initial activities of $\mathbf{1}$ and $\mathbf{2}$ are 179 and $174 \mathrm{~mol} \mathrm{~mol}^{-1}$ Mo $\mathrm{h}^{-1}$, respectively, and both catalysts yield cyclooctene oxide quantitatively after $4 \mathrm{~h}$ (Fig. 1). These results differ with literature data for Lewis base adducts of the $\mathrm{MoO}_{2} \mathrm{X}_{2}$ and $\mathrm{WO}_{2} \mathrm{X}_{2}$ fragments, which up until now have indicated that, for a given ligand, the halide complexes are significantly more active for cyclooctene epoxidation than the methyl derivatives (for cyclooctene epoxidation under reaction conditions identical to those used in the present work). ${ }^{7 c, 10,16}$ Kinetic studies carried out for some of these compounds showed that catalyst formation (represented as MoLyOOR in Scheme 1) is the rate determining step (RDS). ${ }^{16}$ Previously, catalyst systems containing (dimethyl)dioxomolybdenum(VI) complexes have been rather sluggish. ${ }^{7 c}$ For example, compound $\mathbf{2}$ is far more active than $\left[\mathrm{MoO}_{2}\left(\mathrm{CH}_{3}\right)_{2}(N, N\right.$ - $p$-tolyl-1,4-diazabutadiene)], denoted as $\mathbf{3}$ in this work, which yielded only $55 \%$ cyclooctene oxide after $4 \mathrm{~h}$ reaction. ${ }^{7 c}$ The difference between these two compounds is that $\mathbf{3}$ bears an unsubstituted DAB ligand, while compound 2 possesses an alkylated DAB ligand. The differences in catalytic activity may be due to electronic effects. Unsubstituted DAB ligands are more electron-attracting than their C-alkylated counterparts, accounting for a lower electronic density around the Mo centre. Considering the same reaction mechanism for both catalyst systems, TBHP should coordinate more readily to complex $\mathbf{3}$ than to complex $\mathbf{2}$, leading to faster formation of the active oxidizing species responsible for epoxidation. Accordingly, if catalyst formation is the RDS for both systems then one would expect the epoxidation rate to be higher for compound $\mathbf{3}$ than for $\mathbf{2}$, which is not the case. On the other hand, the higher $\pi$-accepting capability of the precursor complex $\mathbf{3}$ in comparison to $\mathbf{2}$ may enhance the competitive coordination of $t-\mathrm{BuOH}$ (instead of TBHP) to the metal centre (to give MoLzOR as represented in Scheme 1), thus slowing down the catalytic reaction. Furthermore, slight differences in solubility between these complexes may also affect the reaction rate.

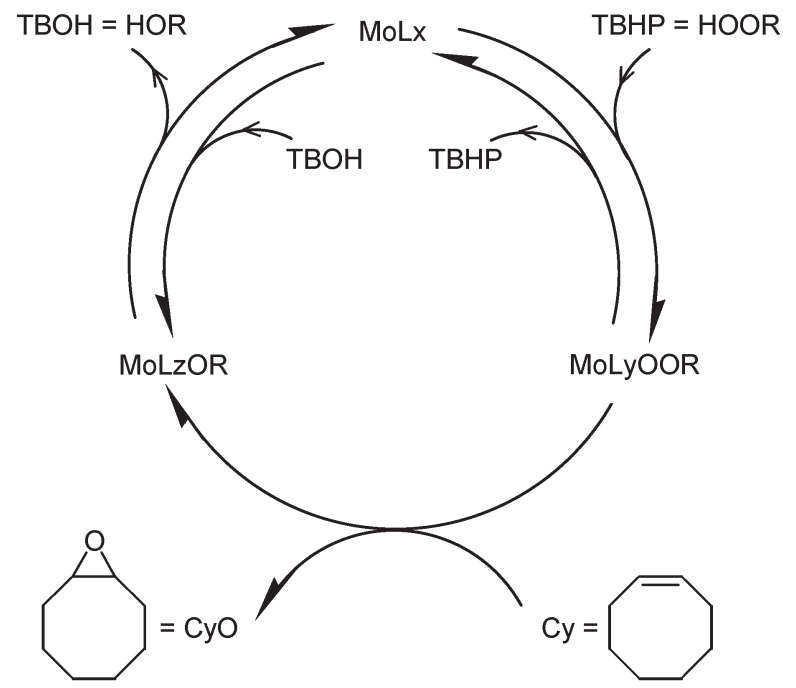

Scheme 1 Main steps involved in the epoxidation of cyclooctene with TBHP catalysed by oxomolybdenum(VI) complexes. The catalyst precursors 1 and 2 are represented as MoLx.

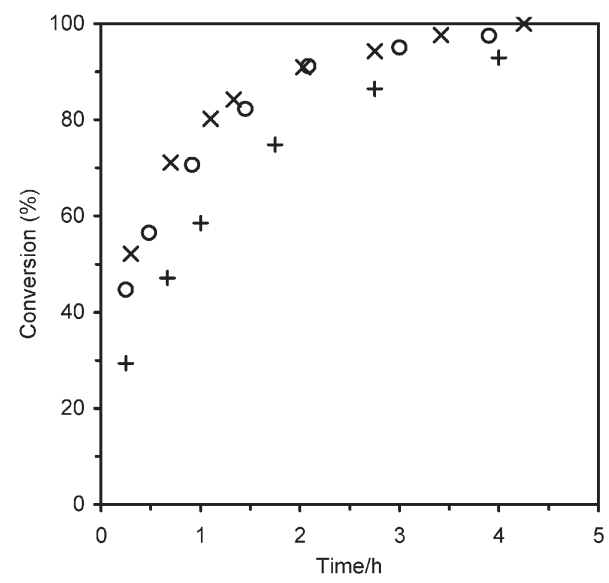

Fig. 1 Kinetics of the epoxidation of cyclooctene (with TBHP in decane), catalysed by compounds $\mathbf{1}(O)$ and $\mathbf{2}$ [first $(\times)$ and second (+) runs]. Reaction conditions: $36 \mu \mathrm{mol}$ catalyst, $3.6 \mathrm{mmol}$ olefin, $5.5 \mathrm{mmol}$ TBHP, $0.4 \mathrm{~mL}$ decane, $T=55^{\circ} \mathrm{C}$.

For the catalyst system containing compound 2, using aqueous TBHP (70 wt \%) instead of the decane solution resulted in a significant decrease in the initial reaction rate (to $51 \mathrm{~mol} \mathrm{~mol}^{-1} \mathrm{Mo} \mathrm{h}^{-1}$ ). This may be due to the fact that the catalyst precursor completely dissolves in the decane solution, but is poorly soluble in the biphasic (aqueous and organic) liquid system. On the other hand, water is a strongly coordinating solvent, which can severely retard the reaction by competing for coordination sites on the catalyst. With aqueous $\mathrm{H}_{2} \mathrm{O}_{2}(30 \%)$, cyclooctene conversion was less than $1 \%$. The epoxidation of cyclooctene catalysed by $\mathbf{2}$ with TBHP in decane was subsequently studied in more detail, including an appraisal of the catalyst stability and measurement of catalytic activity as a function of reaction temperature and initial concentrations of catalyst, cyclooctene and TBHP.

It is known that the high reactivity of the $\mathrm{MoO}_{2}\left(\mathrm{CH}_{3}\right)_{2}$ fragment is stabilised to a certain extent by chelating bidentate ligands. The formation of methane during the epoxidation reaction with 2 was checked by analysing the gas phase in a closed reaction vessel. No methane was detected, suggesting that the $\mathrm{Mo}-\mathrm{CH}_{3}$ bonds of the complex are chemically stable under the specified reaction conditions. The catalyst was also used in a second reaction cycle, under air at $35^{\circ} \mathrm{C}$, by charging an extra $3.6 \mathrm{mmol}$ substrate after $24 \mathrm{~h}$ (Fig. 2). Cyclooctene epoxidation continued, albeit at a lower rate. According to

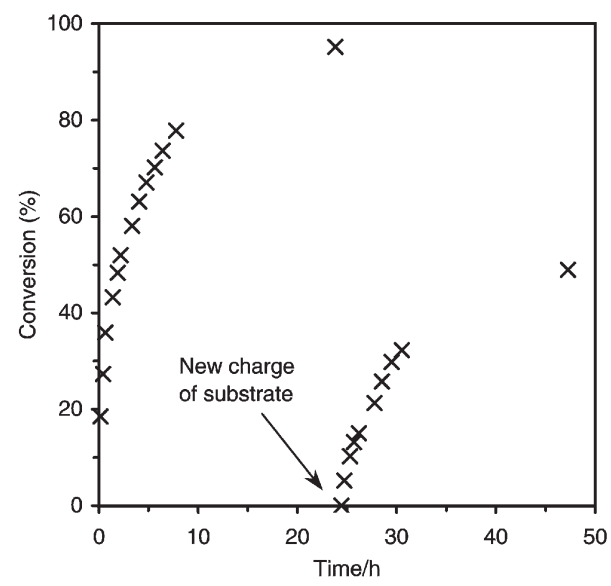

Fig. 2 Kinetics of the epoxidation of cyclooctene (with TBHP in decane) for the two reaction cycles with two charges of olefin at 0 and $24 \mathrm{~h}$, catalysed by compound 2 . Initial reaction conditions: $36 \mu \mathrm{mol}$ catalyst, $3.6 \mathrm{mmol}$ olefin, $5.5 \mathrm{mmol}$ TBHP, $0.4 \mathrm{~mL}$ decane, $T=35^{\circ} \mathrm{C}$. 
the above mechanistic assumptions, the reduced activity is probably due to the lower concentration of TBHP and to the presence of tert-butyl alcohol formed during the first run. Other studies with dioxomolybdenum(vi) complexes as catalysts in this system revealed that the addition of tert-butyl alcohol at the beginning of the reaction decreases the initial rate significantly. ${ }^{10}$ No peroxide was detected by iodometric titration at $50 \mathrm{~h}$ and the number of moles of cyclooctene converted is approximately equal to the amount of peroxide added at the beginning of the reaction. A parallel study was carried out at $55^{\circ} \mathrm{C}$ for which similar results were obtained. The molybdenum complex $\mathbf{2}$ may be easily separated from the reactants and products by adding $n$-hexane to the reaction solution, which causes the complex to precipitate. After drying at room temperature, the recovered solid was used in a second run under identical conditions. The reaction rate decreased slightly, yielding $92 \%$ cyclooctene oxide within $4 \mathrm{~h}$.

Cyclooctene epoxidation with TBHP in decane catalysed by compound 2 was studied in the temperature range $35-75^{\circ} \mathrm{C}$. Product selectivity was not altered and the initial rate increases with temperature. For all experiments, after sufficient time, the epoxidation reaction goes to completion. The effective activation energy was estimated from the slope of the Arrhenius plot at fixed cyclooctene concentration $\left(R^{2}=0.9904\right)$ as $c a .37 \mathrm{~kJ}$ $\mathrm{mol}^{-1}$. The kinetic study of cyclooctene epoxidation in the presence of 2 was carried out using the method of initial rates to determine the reaction orders. The dependence of the reaction rate on the concentration of cyclooctene was studied at $55^{\circ} \mathrm{C}$, varying the initial quantity of cyclooctene $\left(n_{\mathrm{i}}\right)$ from $1.4 \mathrm{mmol}$ to $4.6 \mathrm{mmol}$ [molar ratio substrate:oxidant: catalyst $=(39-128): 153: 1]$. Within this compositional range, the initial rate of reaction $\left(-r_{0}\right)$ exhibits a first-order dependence on initial cyclooctene concentration, determined from the plot of $-r_{0}$ versus $n_{\mathrm{i}}$ (Fig. 3). Finally, all experiments yielded cyclooctene epoxide quantitatively.

The effect of the amount of oxidant on the conversion was the next parameter investigated. The epoxidation does not take place at $55^{\circ} \mathrm{C}$ in the absence of TBHP. Fig. 4 shows that the initial rate of reaction $-r_{0}$ increases with increasing concentration of TBHP. On a logarithmic scale this dependence is linear with a gradient of 0.67 , corresponding to the reaction order in TBHP. The fractional reaction rate order indicates that cyclooctene epoxidation with $\mathbf{2}$ is a complex process including a number of simultaneous and consecutive elementary reactions. This is in agreement with the above assumptions for the reaction mechanism of cyclooctene epoxidation. It is possible that increasing the TBHP concentration increases the TBHP: tert-butyl alcohol molar ratio in the reaction solution,

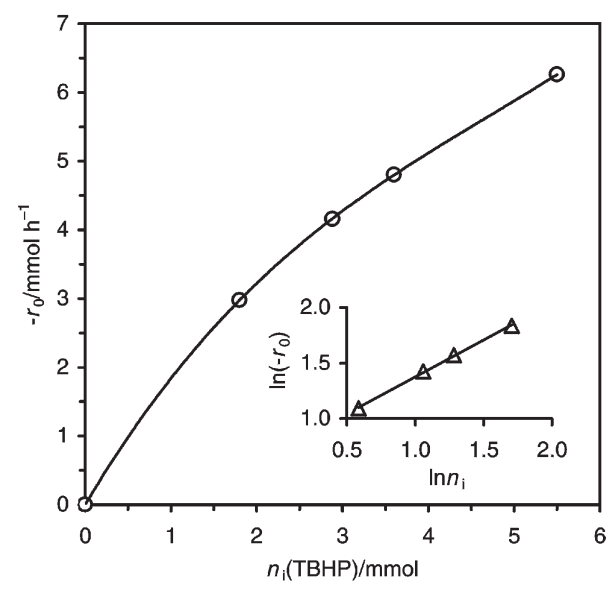

Fig. 4 Dependence of the initial rate of cyclooctene epoxidation (with TBHP in decane), catalysed by compound $\mathbf{2}$, on the initial amount of peroxide. Reaction conditions: $36 \mu \mathrm{mol}$ catalyst, $3.6 \mathrm{mmol}$ olefin, solvent $=$ decane, $T=55^{\circ} \mathrm{C}$.

enhancing the difference between the amount of active oxidising species (formed from TBHP) and inactive species (formed from tert-butyl alcohol), thus explaining the higher catalytic activity for cyclooctene epoxidation. Fig. 5 shows that there is also a rather complex relationship between the $-r_{0}$ and the initial catalyst concentration. The epoxidation rate increases linearly as the initial amount of catalyst reaches $36 \mu \mathrm{mol}$. Further increase in the amount of complex does not enhance the reaction rate significantly. At higher complex concentrations the productive utilisation of TBHP may level off due to its decomposition into $t$ - $\mathrm{BuOH}$ and molecular oxygen. In addition, catalyst solubility problems may arise. All experiments eventually yielded cyclooctene epoxide quantitatively. The above results indicate that the rate law of cyclooctene epoxidation depends on the concentrations of substrate, TBHP and catalyst precursor. Therefore, it is unlikely that for this reaction system catalyst formation is the rate-determining step.

The catalytic performance of $\mathbf{2}$ was further evaluated for the epoxidation of other olefins, namely 1-octene, 2-octene, cyclododecene and $(R)-(+)$-limonene, under typical reaction conditions. For all the olefins tested, except limonene, the catalyst was $100 \%$ selective towards the formation of the corresponding epoxide (Fig. 6). In the case of $(R)-(+)$-limonene, limonene oxide ( $57 \%$ selectivity) is the main product and other epoxides, such as 8,9-epoxy- $p$-menth-1-ene and $\alpha$-limonene diepoxide are formed with $9 \%$ and $29 \%$ selectivity, respectively, at $82 \%$

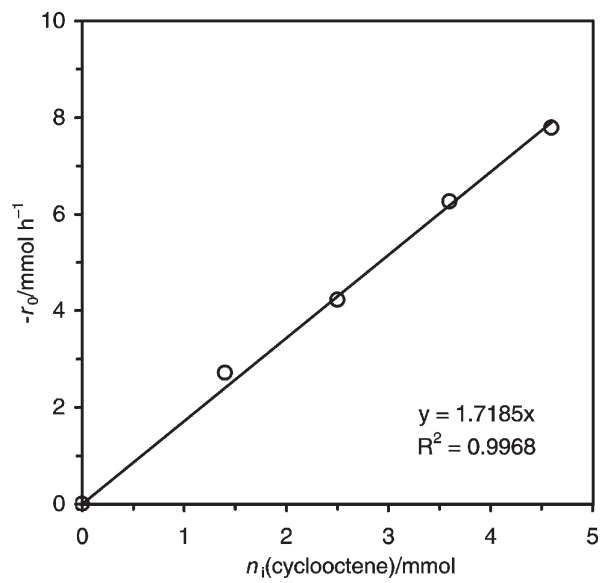

Fig. 3 Dependence of the initial rate of cyclooctene epoxidation (with TBHP in decane), catalysed by compound 2 , on the initial charge of cyclooctene. Reaction conditions: $36 \mu \mathrm{mol}$ catalyst, $5.5 \mathrm{mmol}$ TBHP, solvent $=$ decane, $T=55^{\circ} \mathrm{C}$.

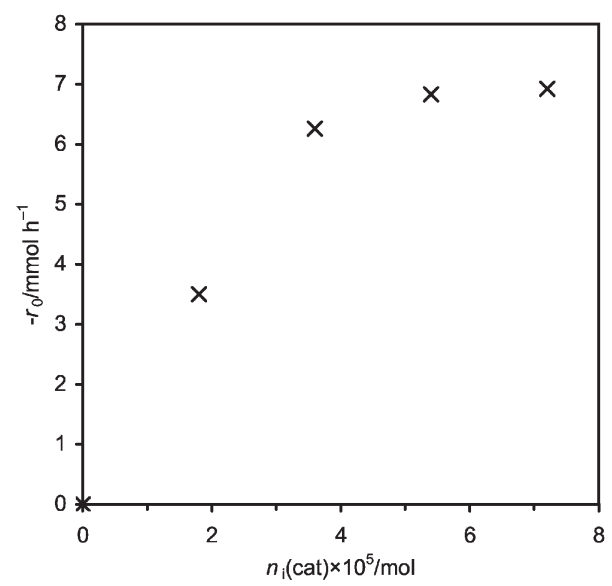

Fig. 5 Dependence of the initial rate of cyclooctene epoxidation (with TBHP in decane), catalysed by compound 2 , on the initial amount of catalyst. Reaction conditions: $3.6 \mathrm{mmol}$ olefin, $5.5 \mathrm{mmol}$ TBHP, solvent $=$ decane, $T=55^{\circ} \mathrm{C}$ 


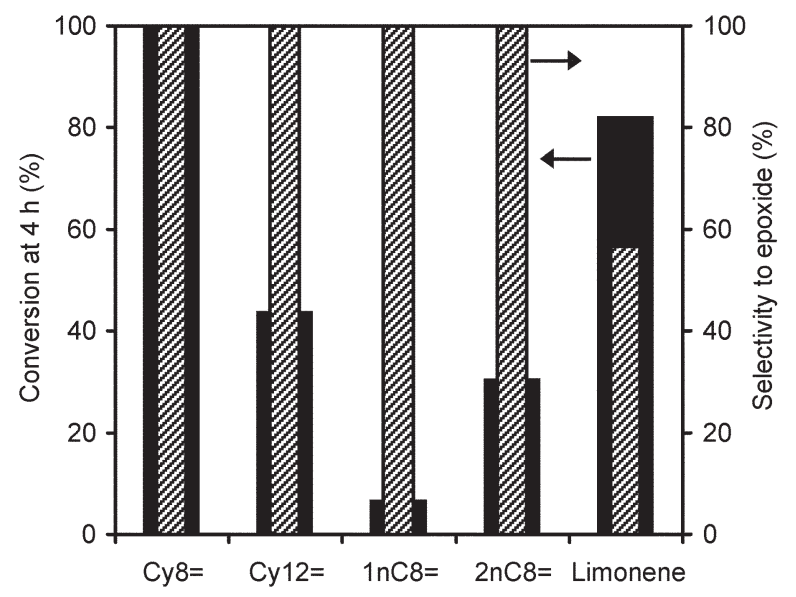

Fig. 6 Conversion (black bars) and selectivity (hashed bars) of cyclooctene $(\mathrm{Cy} 8=)$, cyclododecene $(\mathrm{Cy} 12=)$, 1-octene $(1 \mathrm{nC} 8=)$, 2-octene $(2 \mathrm{nC} 8=)$ and $(R)-(+)$-limonene towards the corresponding epoxide (limonene oxide in the case of limonene) after $4 \mathrm{~h}$ in the presence of 2 .

conversion $(4 \mathrm{~h})$. The results obtained for the epoxidation of 1-octene and 2-octene in the presence of 2 indicate a higher catalytic activity towards the oxidation of internal $\mathrm{C}=\mathrm{C}$ double bonds than of terminal ones, which is probably due to the higher electronic density of the former.

\section{UV/Vis kinetic studies of catalyst formation}

The reaction of the catalyst precursor $\left[\mathrm{MoO}_{2} \mathrm{Cl}_{2}\left\{p\right.\right.$-tolyl $\left(\mathrm{CH}_{3-}\right.$ DAB)\}] (1) with TBHP was followed using UV/Vis spectroscopy, as described in the Experimental. The kinetics of precursor-oxygen donor complex formation shows that the reaction is first order in metal complex and in oxygen donor. The observed rate constants were determined by fitting the absorbance $v s$. time data to eqn. (1):

$$
A_{t}=A_{\infty}\left(1-\mathrm{e}^{-k_{\mathrm{obs}} t}\right)+\text { offset }+L^{*} t
$$

where $A_{t}$ and $A_{\infty}$ are the absorbance at time $t$ and at the end of reaction, respectively, the offset is $A_{0}$ and the $L$ parameter takes into account a very small drift observed in the absorbance $v$ s. time data at the end of the reaction. Fig. 7 shows a typical fit to experimental results using eqn. (1).

The observed pseudo-first-order rate constants, $k_{\text {obs }}$, are summarised in Table 1 . The fit of $k_{\mathrm{obs}}$ values $v s$. oxygen donor concentration shows a clear first-order dependence on [TBHP] and a specific rate of $3.2 \mathrm{~mol}^{-1} \mathrm{dm}^{3} \mathrm{~s}^{-1}$ can be calculated (Fig. 8). This rate constant is some 3 orders of magnitude

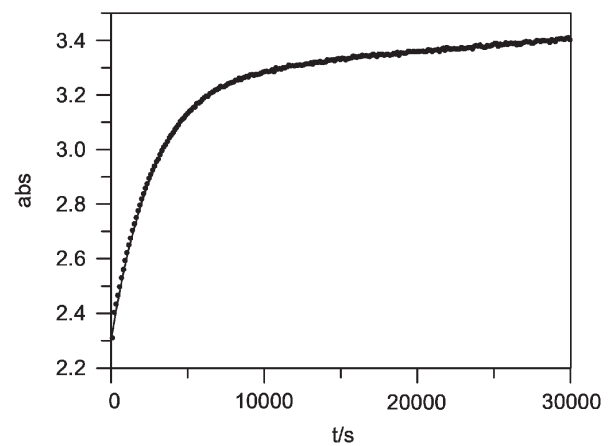

Fig. 7 Absorbance $v s$. time data $(\lambda=300 \mathrm{~nm})$ for the reaction of $\left[\mathrm{MoO}_{2} \mathrm{Cl}_{2}\left\{p\right.\right.$-tolyl $\left.\left.\left(\mathrm{CH}_{3} \mathrm{DAB}\right)\right\}\right]$ with TBHP. Reaction conditions: $\left[\mathrm{MoO}_{2} \mathrm{Cl}_{2}\left\{p\right.\right.$-tolyl $\left.\left.\left(\mathrm{CH}_{3} \mathrm{DAB}\right)\right\}\right]=5.0 \times 10^{-4} \mathrm{M},[\mathrm{TBHP}]=1.0 \times 10^{-3}$ $\mathrm{M}$, solvent $=\mathrm{CH}_{3} \mathrm{CN}$ with less than $1 \%$ of decane, $T=25^{\circ} \mathrm{C}$.
Table 1 Pseudo-first-order observed rate constants, $k_{\mathrm{obs}}$, at different $[\mathrm{TBHP}]$ values. Reaction conditions: $\left[\mathrm{MoO}_{2} \mathrm{Cl}_{2}\left\{p\right.\right.$-tolyl $\left.\left.\left(\mathrm{CH}_{3} \mathrm{DAB}\right)\right\}\right]=$ $5.0 \times 10^{-4} \mathrm{M}$, solvent $=\mathrm{CH}_{3} \mathrm{CN}$ with less than $1 \%$ of decane, $T=25^{\circ} \mathrm{C}$

\begin{tabular}{ll}
\hline $10^{2}[\mathrm{TBHP}] / \mathrm{mol} \mathrm{dm}^{-3}$ & $10^{4} k_{\mathrm{obs}} / \mathrm{s}^{-1}$ \\
\hline 0.5 & $2.06 \pm 0.02$ \\
1.0 & $3.63 \pm 0.01$ \\
2.5 & $10.0 \pm 0.1$ \\
4.0 & $12.4 \pm 0.2$ \\
5.0 & $16.0 \pm 0.2$ \\
\hline
\end{tabular}

greater than that reported for the tungsten complex $\left[\mathrm{WO}_{2} \mathrm{Cl}_{2-}\right.$ (4,4'-di-tert-butyl-2,2'-bipyridine) $]{ }^{16}$ The catalytic efficiency of the molybdenum complex is also considerably greater than that of the tungsten complex for the same probe reaction, epoxidation of cyclooctene. The higher reactivity of $\mathrm{Mo}^{\mathrm{vi}}$ complexes in comparison to their $\mathrm{W}^{\mathrm{vI}}$ analogues can be attributed to a balance between the promptness of metal complex-oxygen donor complex formation and the speed of oxygen transfer to the olefin double bond.

The activation parameters for catalyst formation were determined from kinetic data obtained in the range of $25-60{ }^{\circ} \mathrm{C}$ (Table 2). Fig. 9 shows the fit of the obtained second-order rate constants to the Eyring equation, which gives the values of $\Delta H^{\neq}=48 \pm 3 \mathrm{~kJ} \mathrm{~mol}^{-1}$ and $\Delta S^{\neq}=$ $-112 \pm 10 \mathrm{~J} \mathrm{~mol}^{-1} \mathrm{~K}^{-1}$. These results are completely consistent with the proposed mechanism involving formation of one adduct between the oxygen donor and the metal centre. The numerical values of the activation parameters are quite similar to those reported for the tungsten complex $\left[\mathrm{WO}_{2}\left(\mathrm{C}_{2} \mathrm{H}_{5}\right)_{2}\left(4,4^{\prime}\right.\right.$ di-tert-butyl-2,2'-bipyridine)], ${ }^{16}$ suggesting a similar mechanism with the same energy requirements for the formation of the active oxidising species. It may be concluded that the different catalytic activities for these complexes are imputed to the oxygen transfer from the catalyst to the substrate.

Attempts to make similar kinetic measurements for the complex $\left[\mathrm{MoO}_{2} \mathrm{Me}_{2}\left\{p\right.\right.$-tolyl $\left.\left.\left(\mathrm{CH}_{3} \mathrm{DAB}\right)\right\}\right]$ were unsuccessful since clean $\mathrm{UV} /$ Vis kinetic traces could not be obtained.

\section{Concluding remarks}

The dioxomolybdenum(vi) complexes $\left[\mathrm{MoO}_{2} \mathrm{X}_{2}\left\{p\right.\right.$-tolyl $\left(\mathrm{CH}_{3}\right.$ $\mathrm{DAB})\}](\mathrm{X}=\mathrm{Cl}, \mathrm{Me})$ are highly active and selective catalysts for the homogeneous epoxidation of cyclooctene using tertbutyl hydroperoxide (TBHP). Cyclooctene oxide is obtained quantitatively within $4 \mathrm{~h}$ of reaction and the reaction solution containing the catalyst may be successfully reused. The kinetic results can be interpreted on the basis of the reaction mechanism proposed by Kühn et al. for the epoxidation of cyclooctene in the presence of bipyridine and bipyrimidine

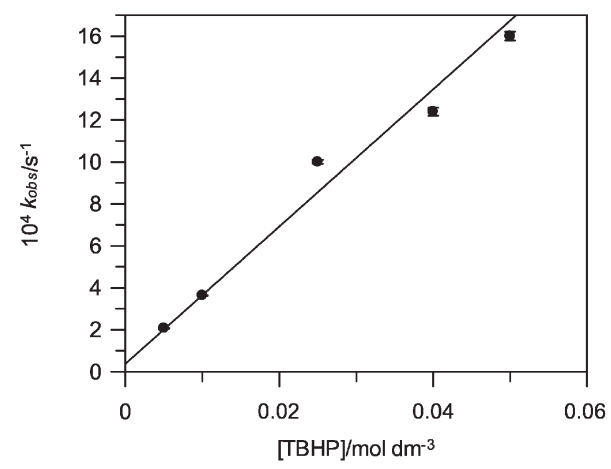

Fig. 8 Pseudo-first-order observed rate constant, $k_{\mathrm{obs}}$, dependence on [TBHP] at $25^{\circ} \mathrm{C}$ in $\mathrm{CH}_{3} \mathrm{CN}$ with less than $1 \%$ of decane. 
Table 2 Second-order rate constants, $k_{2}$, at different temperatures. Reaction conditions: $\left[\mathrm{MoO}_{2} \mathrm{Cl}_{2}\left\{p\right.\right.$-tolyl $\left.\left.\left(\mathrm{CH}_{3} \mathrm{DAB}\right)\right\}\right]=5.0 \times 10^{-4} \mathrm{M}$, solvent $=\mathrm{CH}_{3} \mathrm{CN}$ with less than $1 \%$ of decane

\begin{tabular}{ll}
\hline$T /{ }^{\circ} \mathrm{C}$ & $10^{-1} k_{2} / \mathrm{mol}^{-1} \mathrm{dm}^{3} \mathrm{~s}^{-1}$ \\
\hline 25 & 0.330 \\
40 & 0.880 \\
50 & 1.40 \\
60 & 3.00 \\
\hline
\end{tabular}

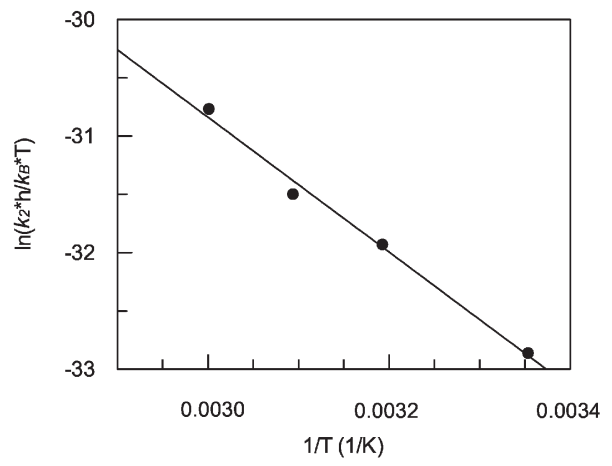

Fig. 9 Fit of the second-order rate constants, $k_{2}$, to the Eyring equation. Reaction conditions: $\left[\mathrm{MoO}_{2} \mathrm{Cl}_{2}\left\{p\right.\right.$-tolyl $\left.\left.\left(\mathrm{CH}_{3} \mathrm{DAB}\right)\right\}\right]=5.0 \times 10^{-4} \mathrm{M}$, solvent $=\mathrm{CH}_{3} \mathrm{CN}$ with less than $1 \%$ of decane.

dioxomolybdenum(vi) complexes. ${ }^{10}$ Cyclooctene epoxidation with $\left[\mathrm{MoO}_{2} \mathrm{Cl}_{2}\left\{p\right.\right.$-tolyl $\left.\left.\left(\mathrm{CH}_{3} \mathrm{DAB}\right)\right\}\right]$ includes a number of simultaneous and consecutive elementary reactions. The catalyst precursor-oxygen donor complex formation is first-order dependent on TBHP and on the metal complex $\left[\mathrm{MoO}_{2} \mathrm{Cl}_{2}\{p\right.$ tolyl $\left.\left.\left(\mathrm{CH}_{3} \mathrm{DAB}\right)\right\}\right]$. The oxidizing agent TBHP is transformed to tert-butyl alcohol during the course of the reaction, which can coordinate to the metal centre and consequently retard the reaction. The initial rate of reaction of cyclooctene epoxidation exhibits a first-order dependence with respect to initial cyclooctene concentration and a fractional $(0.64)$ reaction rate order dependence with respect to initial concentration of TBHP.

\section{Acknowledgements}

This work was partly funded by the FCT, POCTI and FEDER (Project POCTI//QUI/37990/2001). AAV and MP thank the FCT for post-doctoral grants and CN thanks the University of Aveiro for a research grant. The authors are grateful to Prof. João Rocha for generous support.

\section{References}

1 (a) J.-M. Brégeault, J. Chem. Soc., Dalton Trans., 2003, 3289; (b) K. A. Jørgensen, Chem. Rev., 1989, 89, 431.

2 M. H. Dickman and M. T. Pope, Chem. Rev., 1994, 94, 569 and references cited therein.
3 (a) A. Hroch, G. Gemmecker and W. R. Thiel, Eur. J. Inorg. Chem., 2000, 1107; (b) W. R. Thiel and J. Eppinger, Chem.-Eur. J., 1997, 3, 696; (c) W. R. Thiel, J. Mol. Catal., 1997, 117, 449; (d) W. R. Thiel and J. Eppinger, Angew. Chem., Int. Ed. Engl., 1995, 34, 1737 .

4 G. Wahl, D. Kleinhenz, A. Schorm, J. Sundermeyer, R. Stowasser, C. Rummey, G. Bringmann, C. Fickert and W. Kiefer, Chem.-Eur. J., 1999, 5, 3237.

5 (a) A. D. Lopes, Ph.D. Thesis, ITQB/Universidade Nova de Lisboa, Portugal, 1999; (b) A. M. Santos, Ph.D. Thesis, Technischen Universität München, Germany, 2000; (c) J. J. Haider, Ph.D. Thesis, Technischen Universität München, Germany, 1999.

6 (a) W. A. Herrmann, G. M. Lobmaier, T. Priermeier, M. R Mattner and B. Scharbert, J. Mol. Catal. A: Chem., 1997, 117, 455; (b) R. Clarke, M. Gahagan, R. K. Mackie, D. F. Foster, D. J. Cole-Hamilton, M. Nicol and A. W. Montford, J. Chem. Soc., Dalton Trans., 1995, 1221; (c) J. M. Mitchell and N. S. Finney, J. Am. Chem. Soc., 2001, 123, 862; (d) Y.-L. Wong, D. K. P. Ng and H. K. Lee, Inorg. Chem., 2002, 41, 5276 .

7 (a) F. E. Kühn, E. Herdtweck, J. J. Haider, W. A. Herrmann, I. S Gonçalves, A. D. Lopes and C. C. Romão, J. Organomet. Chem., 1999, 583, 3; (b) F. E. Kühn, A. D. Lopes, A. M. Santos, E. Herdtweck, J. J. Haider, C. C. Romão and A. G. Santos, J. Mol. Catal. A: Chem., 2000, 151, 147; (c) F. E. Kühn, A. M. Santos, A. D. Lopes, I. S. Gonçalves, E. Herdtweck and C. C. Romão, J. Mol. Catal. A: Chem., 2000, 164, 25; (d) F. E. Kühn, A. M. Santos, I. S. Gonçalves, C. C. Romão and A. D. Lopes, Appl. Organomet. Chem., 2001, 15, 43.

8 (a) W. A. Herrmann, J. J. Haider, J. Fridgen, G. M. Lobmaier and M. Spiegler, J. Organomet. Chem., 2000, 603, 69; (b) S. Bellemin-Laponnaz, K. S. Coleman, P. Dierkes, J.-P. Masson and J. A. Osborn, Eur. J. Inorg. Chem., 2000, 1645; (c) F. E. Kühn, A. M. Santos, A. D. Lopes, I. S. Gonçalves, J. E. Rodríguez-Borges, M. Pillinger and C. C. Romão, J. Organomet. Chem., 2001, 621, 207; (d) I. S. Gonçalves, F. E. Kühn, A. M. Santos, A. D. Lopes, J. E. Rodríguez-Borges, M. Pillinger, P. Ferreira, J. Rocha and C. C. Romão, J. Organomet. Chem., 2001, 626, 1; (e) A. A. Valente, I. S. Gonçalves, A. D. Lopes, J. E. Rodríguez-Borges, M. Pillinger, C. C. Romão, J. Rocha and X. García-Mera, New J. Chem., 2001, 25, 959.

9 A. M. Santos, F. E. Kühn, K. Bruus-Jensen, I. Lucas, C. C Romão and E. Herdtweck, J. Chem. Soc., Dalton Trans., 2001, 1332 .

10 F. E. Kühn, M. Groarke, É. Bencze, E. Herdtweck, A. Prazeres, A. M. Santos, M. J. Calhorda, C. C. Romão, I. S. Gonçalves, A. D. Lopes and M. Pillinger, Chem.-Eur. J., 2002, 8, 2370.

11 M. Groarke, I. S. Gonçalves, W. A. Herrmann and F. E. Kühn, J. Organomet. Chem., 2002, 649, 108.

12 (a) G. N. Schrauzer, L. A. Hughes, N. Strampach, P. R. Robinson and E. O. Schlemper, Organometallics, 1982, 1, 44; (b) G. N. Schrauzer, E. O. Schlemper, N. H. Liu, Q. Wang, K. Rubin, X. Zhang, X. Long and C. S. Chin, Organometallics, 1986, 5, 2452; (c) G. N. Schrauzer, L. A. Hughes, N. Strampach, F. Ross, D. Ross and E. O. Schlemper, Organometallics, 1983, 2, 481; $(d)$ G. N. Schrauzer, X. Zhang, N. H. Liu and E. O. Schlemper, Organometallics, 1988, 7, 279; (e) G. N. Schrauzer, L. A. Hughes, E. O. Schlemper, F. Ross and D. Ross, Organometallics, 1983, 2, 1163; $(f)$ H. Teruel, N. Romero and I. Henriquez, Transition Met. Chem., 1995, 20, 426

13 R. Colton and I. B. Tomkins, Aust. J. Chem., 1965, 18, 447.

14 H. L. Kraus and W. Huber, Chem. Ber., 1961, 94, 2864.

15 G. van Koten and K. Vrieze, Adv. Organomet. Chem., 1982, 21, 151.

16 F. E. Kühn, W.-M. Xue, A. Al-Ajlouni, A. M. Santos, S. L. Zang, C. C. Romao, G. Eickerling and E. Herdtweck, Inorg. Chem., 2002, 41, 4468 